\title{
Inhibition of bacterial and boar epididymal sperm immunogenicity by boar seminal immunosuppressive component in mice
}

\author{
J. Dostál ${ }^{1}$, L. Veselský ${ }^{2 *}$, M. Marounek ${ }^{3}$, B. Železná ${ }^{2}$ and \\ V. Jonáková \\ ${ }^{1}$ Institute of Animal Physiology and Genetics, Academy of Sciences of the Czech Republic, \\ 27721 Liberchov, Czech Republic; ${ }^{2}$ Institute of Molecular Genetics, Academy of Sciences of the \\ Czech Republic, 16637 Prague, Czech Republic; and ${ }^{3}$ Institute of Animal Physiology and Genetics, \\ Academy of Sciences of the Czech Republic, 10400 Uhrinerves, Czech Republic
}

\begin{abstract}
Intravenous deposition of the immunosuppressive component, isolated from boar seminal vesicle secretion, led to suppression of primary and secondary antibody response to boar epididymal spermatozoa and to bacterial antigens. The most effective suppression of the immune response was achieved in female mice treated with immunosuppressive component 3 days before the immunization with antigen. The treatment with immunosuppressor 3 days after the immunization resulted in less effective immunosuppression. After the primary immunization, male mice displayed low sensitivity to epididymal spermatozoa. The production of $\operatorname{IgG}$ and $\operatorname{IgM}$ antibodies to spermatozoa was depressed for a relatively long period in female mice treated with immunosuppressor. The immunosuppressive components of the reproductive gland secretions may protect sperm cells from the adverse effect of the immune system cells and enhance the chance of conception. However, seminal immunosuppressive components may play an unfavourable role by producing a predisposition in the reproductive tract to bacterial or viral infections.
\end{abstract}

\section{Introduction}

In the male and female genital tracts, many cells belonging to the immune system (for example, $\mathrm{B}$ and $\mathrm{T}$ lymphocytes, macrophages) are physiological residents (Anderson and Hill, 1989) apparently serving the function of protecting these tracts against the invasion of nonself elements or macromolecules. Therefore, there is the possibility that after insemination the foreign spermatozoa may be damaged in the female reproductive tracts by a local cell-mediated immune reaction (Alexander and Anderson, 1987). However, insemination with homologous spermatozoa normally does not invoke an antisperm immune response. The role of the accessory gland secretions may be to enable the ejaculated spermatozoa to survive in the reproductive tract, particularly after the encounter with cells of the female immune system. The abrogation of the immune response is important for successful conception (James and Hargreave, 1984) but results in other essential immunological events also being suppressed. In vivo studies have demonstrated that seminal plasma components can impair the generation of cytotoxic $T$ cells, the response of $B$ cells to a variety of antigens (Emoto et al., 1990; Shivaji et al., 1991), the cytotoxic effect of natural killer (NK) cells and activated human anti-tumour effector cells (James and Szymaniec, 1985; Ress et al., 1986). Ablin et al. (1980a, b) demonstrated that human

*Correspondence.

Received 7 April 1997. seminal plasma suppresses the humoral and cell-mediated tumour-associated immunity in patients with cancer of the prostate.

Immunosuppressive seminal plasma components can also decrease the anti-bacterial activity mediated by the immune system cells. The mitogen-activated T lymphocytes, separated from the spleen of mice immunized with Listeria monocytogenes and deposited with immunosuppressive components isolated from the mouse testicular or seminal vesicle fluid, did not respond to the Listeria antigens (Emoto et al., 1990, 1991). Similarly, a non-dialysable immunosuppressive component of bull seminal plasma was found to inhibit the neutrophil phagocytic ability of both spermatozoa and Staphylococcus aurets in bactericidal assay (Strzemienski, 1989). The treatment of human peripheral blood lymphocytes with an immunosuppressive component, isolated from human seminal plasma, caused a significant inhibition of anti-bacterial activity against Salmonella typhi and S. minnesota (De Simone et al., 1988).

The physicochemical characterization of seminal plasma has provided evidence that transglutaminase, together with rat seminal immunosuppressive component and prostaglandins, is the principal molecule contributing to seminal plasma immunosuppression of the macrophages and NK cells (Tarter et al., 1986; Ablin et al., 1990; Peluso et al., 1994). Kelly et al. (1991) have demonstrated that prostaglandins of the $\mathrm{E}$ series are almost entirely responsible for the immunosuppression of the NK cell system. Nevertheless, seminal plasma is a complex 
mixture and there is evidence of other immunosuppressive components present in seminal secretions (Nocera and Chu, 1993; Skibinski et al., 1994; Chu et al., 1996).

The absorption of the immunosuppressive component (immunosuppressive fraction, ISF) isolated from boar seminal vesicle secretion onto the surface of white blood cells after its intraperitoneal or rectal administration to $\mathrm{BALB} / \mathrm{c}$ mice has been shown to cause a decrease in the number of lymphocytes in the blood of treated mice without altering the concentration of the granulocytes (Dostál et al., 1995). ISF was also detected on the membrane of the B-cell lymphocyte subpopulation isolated from the spleen of mice treated intraperitoneally and rectally with ISF (Dostál et al., 1995). Deposition of ISF in vivo significantly reduced the proliferative activity of mitogenstimulated B lymphocytes. However, seminal immunosuppressor was not detected on T-cell membrane and T-cell proliferation was not abrogated by ISF (Veselský et al., 1996).

The aim of the present study was to determine the ability of ISF, administered in vivo, to inhibit the primary and secondary antibody response to spermatozoal and bacterial antigens in mice. The duration of the immune suppression induced by treatment with ISF and the effect of ISF on the production of immunoglobulin classes within the primary and secondary immunizations were also studied.

\section{Materials and Methods}

\section{Isolation of the immunosuppressive fraction and inhibition of lymphocyte proliferation}

ISF was isolated from boar seminal secretion using the procedure described by Dostál et al. (1995). The effect of ISF on lymphocyte proliferation was tested by an immunoassay system for the detection of incorporation of bromodeoxyuridine (Amersham International kit, Little Chalfont, Herts). The proliferative activity was evaluated using the instructions supplied with the proliferative assay kit, with the mitogen-stimulated lymphocytes from the spleen of mice treated with ISF in vivo. The detailed procedure is described by Veselský et al. (1996).

\section{Preparation of cells}

The ruminal strain of Enterococcus faecium $3 / 5$ was kindly supplied by the Institute of Animal Physiology (Košice, Slovakia). Culture was stored at $-20^{\circ} \mathrm{C}$ in $20 \%(\mathrm{v} / \mathrm{v})$ glycerol in PY medium $(0.5 \mathrm{~g}$ peptone, $0.5 \mathrm{~g}$ trypticase, $1 \mathrm{~g}$ yeast extract, $0.1 \%$ solution of resazurine in water $(\mathrm{w} / \mathrm{v}), 4 \mathrm{ml}$ salt solution $\left(0.2 \mathrm{~g} \mathrm{CaCl}_{2}, 0.2 \mathrm{~g} \mathrm{Mg} \mathrm{SO}_{4}, \mathrm{Ig} \mathrm{K}_{2} \mathrm{HPO}_{4}, 10 \mathrm{~g} \mathrm{Na}\right.$ $\mathrm{HCO}_{3}$, and $2 \mathrm{~g} \mathrm{NaCl}$ per litre of distilled water), $1 \mathrm{ml}$ hemin solution ( $50 \mathrm{mg}$ hemin in $1 \mathrm{ml} 0.5 \mathrm{~mol} \mathrm{NaOH}), 0.02 \mathrm{ml}$ vitamin $\mathrm{K}_{1}\left(0.15 \%\right.$ vitamin $\mathrm{K}_{\mathrm{I}}$ in $30 \mathrm{ml}$ of $95 \%$ ethanol $\left.\mathrm{v} / \mathrm{v}\right)$ per $\left.100 \mathrm{ml}\right)$ before use. The bacteria were grown anaerobically, under $\mathrm{CO}_{2}$ atmosphere, at $39^{\circ} \mathrm{C}$ on the PY medium with glucose $\left(10 \mathrm{~g} \mathrm{l}^{-1}\right)$ as the substrate (Holdeman et al., 1977). The medium was reduced by $0.05 \%(w / v)$ cysteine $-\mathrm{HCl}$. E. faecium was cultured overnight, and then $5 \mathrm{ml}$ was centrifuged for $20 \mathrm{~min}$ at $11000 \mathrm{~g}$, washed three times in PBS, and a suspension of bacterial cells $\left(1 \times 10^{8} \mathrm{ml}^{-1}\right)$ was prepared.
Boar epididymal spermatozoa were obtained from slaughtered animals. The epididymis was separated from the testis and filled with air by means of an injection syringe and a needle inserted into the vas deferens. A mixture of spermatozoa and fluid was obtained by inserting another needle into the cauda epididymis duct. Spermatozoa were sedimented by centrifugation at $3500 \mathrm{~g}$ for $15 \mathrm{~min}$, washed three times and resuspended at a concentration of $1 \times 10^{8}$ cells $\mathrm{ml}^{-1}$ PBS.

\section{Inhibition of the primary antibody response}

The ability of ISF to suppress the primary antibody response to spermatozoa was evaluated in three experiments. In Expt I, $15 \mathrm{BALB} / \mathrm{c}$ female mice were injected i.v. with $100 \mu \mathrm{g}$ ISF in $0.1 \mathrm{ml}$ PBS on days 0,1 and 2 . On day 3 the mice were immunized i.p. with $1 \times 10^{7}$ epididymal spermatozoa in $0.1 \mathrm{ml}$ PBS.

In Expt 2, 15 female mice were immunized i.p. with $1 \times 10^{7}$ epididymal spermatozoa on day 0 and were injected i.v. with $100 \mu \mathrm{g}$ ISF in $0.1 \mathrm{ml}$ PBS on days 0,1 and 2 .

In Expt 3, 15 female mice were immunized i.p. with $1 \times 10^{7}$ epididymal spermatozoa on day 0 , and received i.v. injection of $100 \mu \mathrm{g}$ ISF on days 3, 4 and 5 .

The ability of ISF to suppress the primary antibody response to $E$. faecium was also evaluated. Fifteen male and 15 female mice were injected i.v. with $100 \mu \mathrm{g}$ ISF in $0.1 \mathrm{ml}$ PBS on days 0,1 and 2 each. On day 3 , the mice were immunized i.p. with $1 \times 10^{7}$ bacterial cells in $0.1 \mathrm{ml}$ PBS.

Saline instead of ISF was administered to controls using the same immunization procedure. Antibody titres to epididymal spermatozoa or bacterial cells were measured by ELISA in the blood serum of experimental and control mice 10 days after the immunization. Antisera to spermatozoa were preabsorbed with lyophilized boar epididymal fluid $(0.4 \mathrm{mg}$ protein in $100 \mathrm{ml}$ of antisera) at $37^{\circ} \mathrm{C}$ for $1 \mathrm{~h}$, and then incubated overnight at $4^{\circ} \mathrm{C}$.

\section{Inhibition of secondary antibody response}

The effect of ISF on secondary antibody response was examined in a group of 15 male and 15 female mice immunized with $1 \times 10^{7}$ epididymal spermatozoa in $0.1 \mathrm{ml} \mathrm{PBS}$. On days 17, 18 and 19 , the mice were treated i.v. with $100 \mu \mathrm{g}$ ISF. On day 20 , they were immunized with spermatozoa for a second time. Antibody titres were measured by ELISA in the sera obtained 10 days after the first immunization and 10 days after the second immunization. Saline instead of ISF was administered to a control group using the same immunization procedure.

\section{Duration of the immune suppression}

The duration of the immune suppression induced by treatment with ISF after primary and secondary immunization was determined. The i.v. treatment of female mice with $50 \mu \mathrm{g}$ and $100 \mu \mathrm{g}$ ISF continued for 6 days. On day 4 of ISF treatment, all the mice were immunized i.p. with $1 \times 10^{7}$ epididymal spermatozoa in $0.1 \mathrm{ml}$ PBS. The mice received additional immunizations with epididymal spermatozoa on days 20 and 
40 after the first immunization. The control female mice were immunized with spermatozoa but received saline instead of ISF. Blood samples were taken on days 10, 20, 25, 30, 35 40, 45 and 50 , and antibody titres to spermatozoa were measured by ELISA. These antisera to epididymal spermatozoa from experimental and control female mice were also used to evaluate the production of immunoglobulin isotypes.

\section{ELISA}

The microtitre plates were incubated with $0.01 \%(\mathrm{w} / \mathrm{v})$ poly L-lysine (Sigma, St Louis, MO) in PBS at $22^{\circ} \mathrm{C}$ for $1 \mathrm{~h}$. After washing, the plates were filled with $100 \mu$ l epididymal spermatozoa $\left(2 \times 10^{6}\right.$ cells $\left.\mathrm{ml}^{-1}\right)$ or with $100 \mu \mathrm{l}$ E. faecium $\left(1 \times 10^{7}\right.$ cells $\left.\mathrm{ml}^{-1}\right)$ and incubated at $4^{\circ} \mathrm{C}$ for $18 \mathrm{~h}$. The plates were washed with PBS Tween (PBS containing 0.1\% Tween 20 , $1 \% \mathrm{BSA}$ and $1 \%$ non-fat milk $(\mathrm{w} / \mathrm{v}))$. The wells with $E$. frecium cells were incubated for $20 \mathrm{~min}$ at $22^{\circ} \mathrm{C}$ with a methanolhydrogen peroxidase mixture $\left(100 \mu \mathrm{l} 30 \% \mathrm{H}_{2} \mathrm{O}_{2}, 0.9 \mathrm{ml} \mathrm{H} \mathrm{H}_{2} \mathrm{O}\right.$ and $4 \mathrm{ml}$ methanol) to inhibit endogenous peroxidase (Landsdorp et al., 1980). The plates were washed again with PBS Tween; serially diluted antisera to epididymal spermatozoa or E. faecium from mice deposited with ISF were then added and incubated at $22^{\circ} \mathrm{C}$ for the next $1 \mathrm{~h}$. The plates were washed and pig anti-mouse IgG serum conjugated with peroxidase (USOL, Prague) diluted 1:3000 was added. Bound peroxidase activity was detected using $\mathrm{O}$-phenylenediamine and $\mathrm{H}_{2} \mathrm{O}_{2}$ as substrate. Absorbance was detected at $492 \mathrm{~nm}$. Antisera of mice immunized with spermatozoa or bacteria but untreated with ISF served as positive controls. Sera of mice treated with saline alone were used as blank reference samples. Reactions were considered positive if absorbance values of the test samples were more then twice that of blank reference samples. The titre is the value of the highest sample dilution still giving positive results.

\section{Estimation of immunoglobulin isotype}

The procedure of Mori et al. (1994) was used to estimate the amounts of antisperm $\operatorname{IgM}, \operatorname{Ig} G$ and $\operatorname{Ig} A$ antibodies in the antisera of control (untreated with ISF) and experimental (ISF-treated) mice.

Microtitre wells pretreated with poly L-lysine were coated with $100 \mu \mathrm{l}$ of $2 \times 10^{6}$ spermatozoa ml $\mathrm{ml}^{-1}$ overnight at $4^{\circ} \mathrm{C}$. The coated wells were blocked for $\mathrm{Ih}$ at $37^{\circ} \mathrm{C}$ with PBS Tween. The same antisera to epididymal spermatozoa used for estimation of the duration of the immune suppression were diluted 1:1000 with PBS Tween and incubated with coated wells for $\mathrm{I} \mathrm{h}$ at $23^{\circ} \mathrm{C}$. The plates were washed with PBS Tween, and affinity-purified goat horseradish peroxidase-conjugated antibodies to mouse $\operatorname{IgM}, \operatorname{IgG}$ and $\operatorname{Ig} A$ (heavy chain-specific) diluted 1:4000 were added (Sigma, Deisenhofen). Bound peroxidase activity was detected using $O$-phenylenediamine and $\mathrm{H}_{2} \mathrm{O}_{2}$ as substrate. The reaction was terminated at $30 \mathrm{~min}$ with $2 \mathrm{~mol} \mathrm{H}_{2} \mathrm{SO}_{4} \mathrm{l}^{-1}$ and absorbance at $492 \mathrm{~nm}$ was recorded.

\section{Statistical analysis}

The significance of the differences between experimental and control groups was analysed using Student's $t$ test.

\section{Results}

Isolation of the immunosuppressive fraction and suppression of the proliferative response of lymphocytes

The ISF isolated from seminal vesicle secretion was finally purified by RP HPLC. One millilitre of seminal vesicle secretion yielded $100-200 \mu \mathrm{g}$ ISF. The molecular mass of ISF estimated on a Lasermat Mass Analyzer (Finnigam MAT, San Jose, CA) was $14 \mathrm{kDa}$ (Dostál et al., 1995). Mice were pretreated i.v. with ISF to examine whether the deposition of ISF affects the mitogenic activity of mouse lymphocytes. On day 5 after ISF injection, spleen cells from the treated mice were prepared and assayed for cell proliferation upon stimulation with mitogens in vitro. The proliferative activity of lymphocytes treated with ISF and stimulated by mitogens in vivo was significantly reduced in the immunoassay system for detection of bromodeoxyuridine incorporation $(P<0.01$; Dostál et al., 1995; Veselský et al., 1996).

\section{Suppression of primary antibody response}

Immunization with spermatozoa did not significantly challenge the primary antibody response in males treated with ISF or in control mice. Low titres of anti-sperm antibodies were found in about $50 \%$ of the antisera of control males. Hence, in experiments examining the suppression of the primary antibody response, only female antisera to spermatozoa were evaluated. However, the secondary immunizations of males did challenge the antibody response to spermatozoa.

The immunosuppressive effect of ISF on the antibody response to spermatozoa was evaluated in female sera obtained at different times before and after immunizations (Fig. 1). Maximum immunosuppression of the antibody response was observed in the antisera of female mice treated with ISF 3 days before immunization with spermatozoa $(76 \% ; P<0.01)$. Similar suppression of antibody response was observed in the antisera obtained from female mice treated with ISF for 3 days, beginning on the day of immunization with spermatozoa $(70 \%$, $P<0.01$ ). Treatment with ISF 3 days after immunization with spermatozoa resulted in less effective immunosuppression (55\%; P< 0.05).

Intravenous administration of ISF 3 days before immunization of male and female mice with E. faecium (Fig. 1) also significantly reduced the primary antibody response $(63 \%$; $P<0.01)$

\section{Suppression of secondary antibody response}

The effect of ISF on the secondary antibody response was examined in male and female mice immunized with spermatozoa on day 0 . On days 17,18 and 19 the mice were injected i.v. with ISF or saline. On day 20 the control and experimental mice received a secondary immunization with spermatozoa. Antibody titres to spermatozoa rose from $1440 \pm 533$ in the sera of females treated with ISF after the primary immunization to $2340 \pm 695$ in the sera after the secondary immunization. In females treated with saline, titres to spermatozoa rose from $1320 \pm 474$ in the sera after the primary immunization to 


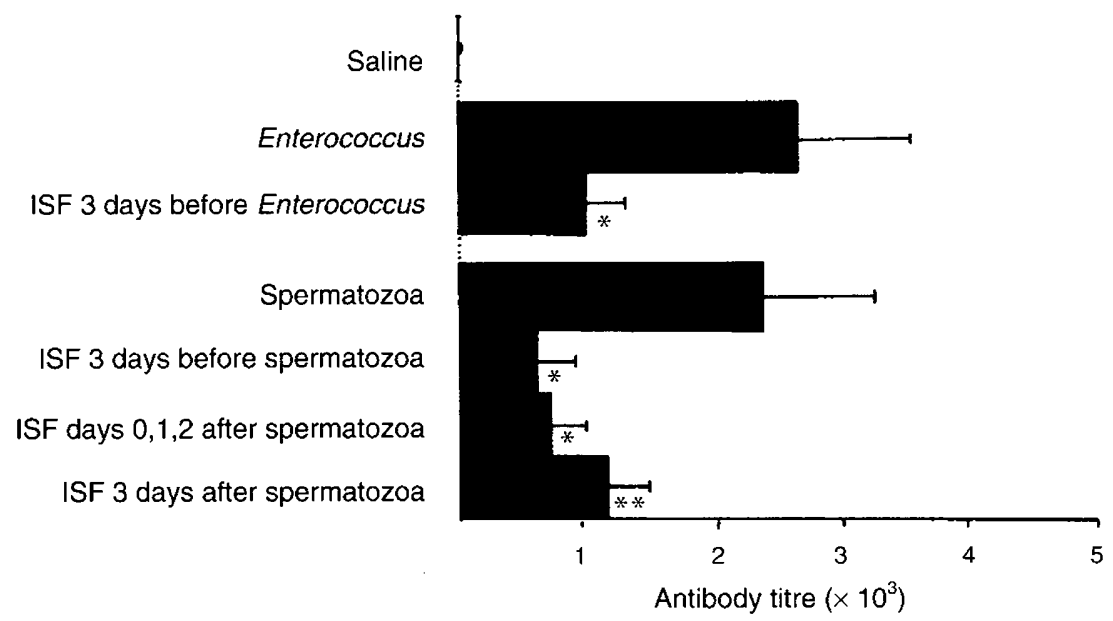

Fig. 1. The effect of intravenous deposition of the immunosuppressive fraction ISF from boar seminal fluid on antibody response in mice to Enterococcus faecium and boar epididymal spermatozoa, as evaluated by ELISA at different intervals before and after immunizations. Values are expressed as the mean $\pm \mathrm{sD}$ from three experiments with five mice in each group. ${ }^{*} P<0.01 ; * P<0.05$ versus control mice.

$8200 \pm 1800$ in the sera after the secondary immunization $(P<0.01)$. Suppression of antibody response to spermatozoa in the male sera obtained after the secondary immunization was also significant. In males immunized with spermatozoa and treated with ISF, the antibody response suppression was $77 \%$ (antibody titre $1200 \pm 538$ ) compared with the antibody titre in the sera of control males $(5120 \pm 1816 ; P<0.01)$.

\section{Duration of immune suppression}

The duration of the immune suppression induced by ISF treatment after the primary and secondary immunizations of female mice with epididymal spermatozoa was determined (Fig. 2). Treatment with $100 \mu \mathrm{g}$ ISF suppressed the primary antibody response to spermatozoa by $81 \%$ compared with antibody titres in the antisera of control mice. Suppression of the secondary antibody response with $100 \mu \mathrm{g}$ ISF was also significant (66\% suppression). However, in mice treated with $50 \mu \mathrm{g}$ ISF, inhibition of the primary and secondary antibody response was not significant.

Similarly, the suppression of the antibody response to spermatozoa after the third immunization (on day 40) was not significant in any experimental groups.

Effect of the immunosuppressive fraction on production of immunoglobulin classes after immunization with spermatozoa

The administration of $100 \mu \mathrm{g}$ ISF significantly affected the production of immunoglobulins in female mice immunized with spermatozoa (Fig. 3). Control mice immunized with spermatozoa and not treated with ISF exhibited an enhanced IgM response to challenging antigens from day 10 to day 50 after the primary and secondary immunizations, with maximum titres on day 25 and day 45 after the primary immunization. However, ISF treatment of immunized mice resulted in significant inhibition of $\operatorname{IgM}$ production. The difference in the suppression of the $\operatorname{IgM}$ antibody response to spermatozoa between mice treated with ISF and controls was not significant from day 45 after the primary immunization.

$\operatorname{Ig} G$ antibody titres determined in the antisera collected from the primary immunized control mice were low in comparison with the titres determined in the antisera of control mice collected after the secondary immunizations. IgG antibodies to spermatozoa in the antisera collected from primary immunized mice treated with ISF (days 10 and 20) were not detectable; however, low titres of $\lg G$ antibodies to spermatozoa were detected in the antisera after the secondary immunization (days $25-40$ ). In this case, the difference in the suppression of IgG antibody response to spermatozoa between mice treated with ISF and controls was not significant from day 45 after the primary immunization.

IgA antibodies to spermatozoa antigens were not detected either in the sera of mice treated with ISF or in controls.

\section{Discussion}

Seminal immunosuppressive components suppress a variety of immunological functions in vitro and in vivo (Quayle et al., 1989; Veselský et al., 1991). Seminal plasma expresses a number of semen-specific antigens that can elicit the immune response in sexual partners (Ablin and Gonder, 1985). Immunization with spermatozoa produces infertility in experimental animals, and antibodies directed against spermatozoal antigens have been detected and associated with infertility in animals and humans (Alexander, 1988; Bérube and Sullivan, 1994). Removal of the seminal vesicles reduces fertility, and suggests that the role of accessory gland secretions may be to enable the ejaculated spermatozoa to survive in the reproductive tract, particularly after the encounter with cells of the female immune system (Peitz and Olds-Clarke, 1986). Studies on different species have demonstrated that ejaculated spermatozoa, although bearing on their surface antigenic determinants, are poor antigens, possibly as a consequence of masking events operated by specific proteins present in seminal plasma 


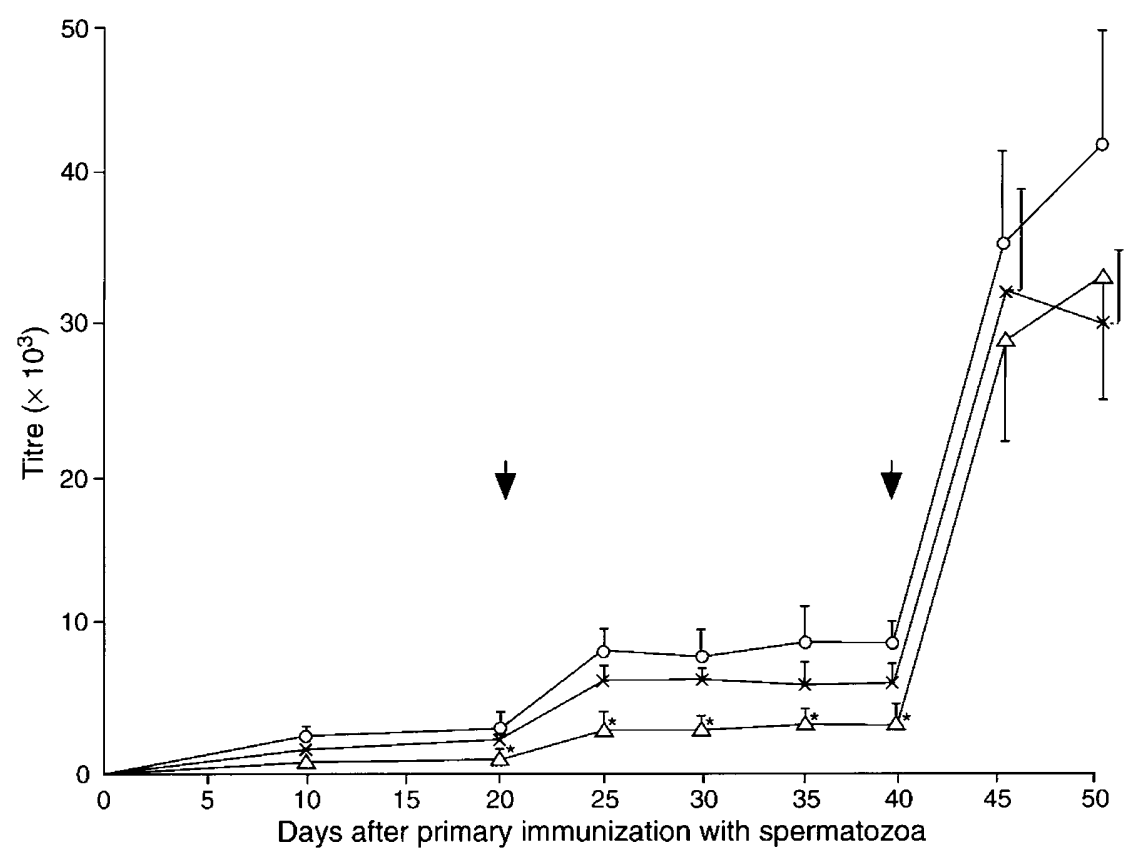

Fig. 2. Duration of immune suppression in mice elicited by the immunosuppressive fraction ISF from boar seminal fluid. Female mice were immunized with boar epididymal spermatozoa only $(O)$ or treated with spermatozoa plus $100 \mu \mathrm{g} \operatorname{ISF}(\triangle)$ or $50 \mu \mathrm{g} \operatorname{ISF}(x)$. Treatment with ISF was continued for 6 days and serum titres of antibodies to spermatozoa were measured by ELISA. All mice received further immunizations with spermatozoa on day 20 and day 40 (arrows). Values are expressed as the mean $\pm \mathrm{sD}$ for five animals at each time point. ${ }^{*} P<0.01$ versus control female mice.

(Anderson and Tarter, 1982; James and Hargreave, 1984). Peritoneal macrophages become strongly activated when challenged with epididymal spermatozoa either in vivo or in vitro (Anderson and Tarter, 1982). The pretreatment of epididymal spermatozoa with rat seminal vesicle secretory protein significantly reduces macrophage activation, most probably as a consequence of a marked decrease in sperm cell antigenicity (Peluso et al., 1994). In the present study, the immune response of male mice to epididymal spermatozoa after the primary immunization was reduced. Low titres of anti-spermatozoal antibodies were found only in about $50 \%$ antisera of males primary immunized with spermatozoa but not treated with ISF. Secondary immunization with spermatozoa challenged a stronger antibody response in all immunized males but antibody production was also suppressed by treatment with ISF. These findings indicate that females are more sensitive to heterogenic spermatozoal antigens. The cervix, uterus and oviduct, as well as the peritoneum, are immunologically dynamic tissues; however, i.p. injection of ejaculated spermatozoa in women evokes an adverse immune reaction against spermatozoa in only a few cases (Livi et al., 1990). This finding indicates that immunosuppressive components in seminal plasma also induce a decrease in the immunogenicity outside the reproductive tract.

The leucocyte function may be paralysed by seminal immunosuppressive factors but semen macrophages retain their phagocytic adherent and motile functions (Anderson and Hill, 1989). The attempts in the present study to induce tolerance in vivo to the challenging antigens using ISF provides evidence that the boar seminal immunosuppressor is more effective in suppression of antibody production than in the transplantation models. No effect of ISF has been demonstrated on cells involved in transplantation events, including NK cell activity (Veselský et al., 1992). However, the finding that seminal ISF inhibits the antibody response to bacterial antigens, together with the report of Goldiero et al. (1989) that the rat seminal immunosuppressive component inhibits peritoneal macrophage ability to phagocyte saprophytic or pathogenic microorganisms, suggests that seminal immunosuppressive components may interfere with immune functions associated with a number of pathological states and may be the factors decreasing an immune response and causing a vulnerability of the reproductive tract to chronic bacterial or viral infections.

Boar seminal ISF may impede the development of humoral immune response by reducing lymphocyte proliferation and inhibiting the antibody response after deposition in vivo (Veselský et al., 1996). The most important outcome of the present study is the evidence that ISF inhibits the antibody response to challenging antigens, including the abrogation of the production of immunoglobulin classes. The most effective inhibition of the antibody response was recorded when ISF was applied before immunization. These results indicate that the pre-exposure is needed for maximal suppression of the primary antibody production and that ISF is less effective on lymphocytes presensitized with antigens. The effect of ISF on white blood cells depends, as expected, on its half-life. The duration of the immunosuppression that was induced by treatment with ISF in vivo within the primary and secondary immunizations was determined and indicates that treatment with ISF leads to prolonged immunosuppression but not to 

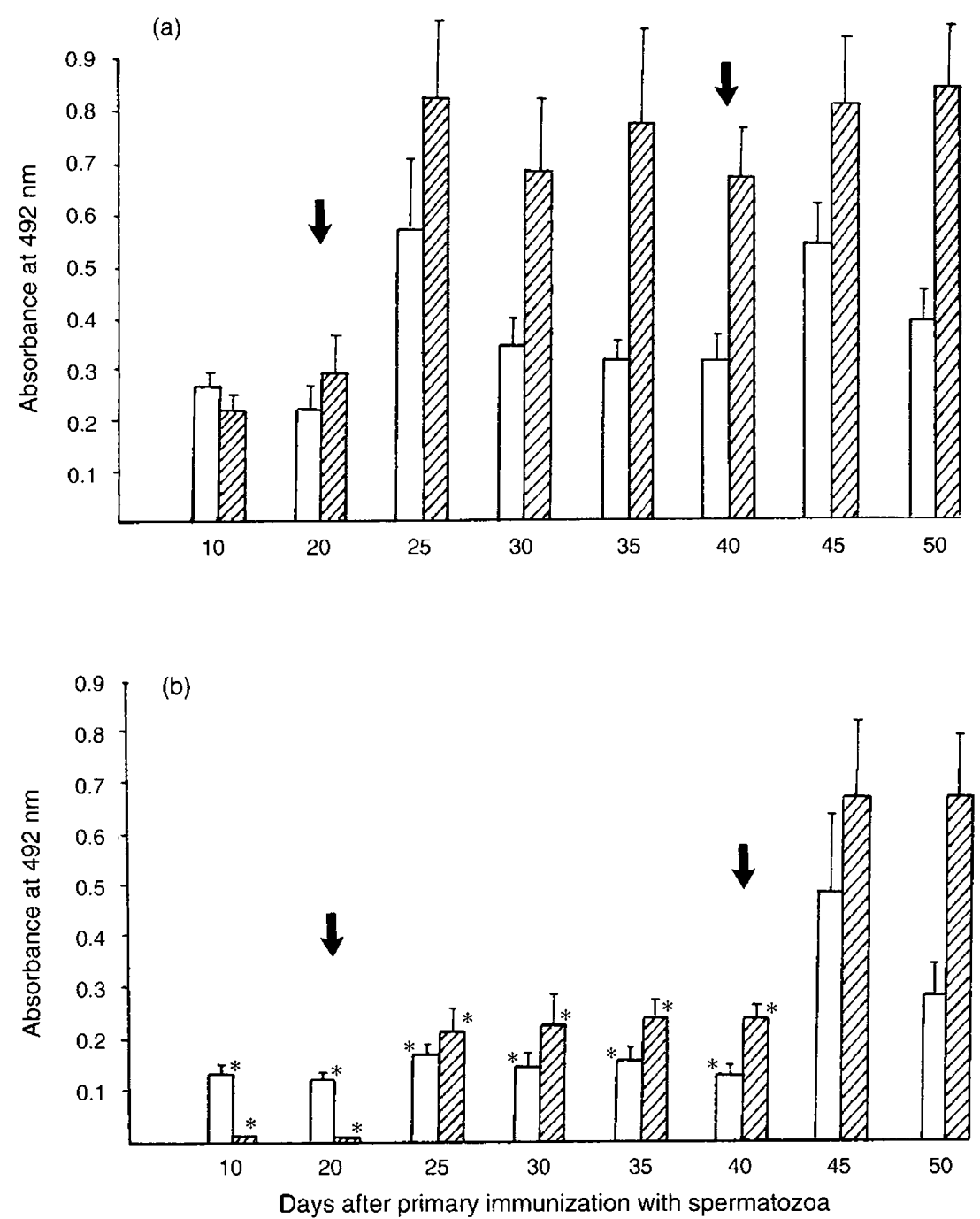

Fig. 3. Effect of $100 \mu \mathrm{g}$ immunosuppressive fraction ISF from boar seminal fluid on production of immunoglobulin classes $(\square, \operatorname{Ig} M ; \nabla, \lg G)$ in mice. The results are expressed as absorbance at $492 \mathrm{~nm}$ in the antisera from (a) female mice immunized against boar epididymal spermatozoa (control group) and (b) female mice immunized against spermatozoa and treated with ISF (experimental group). Additional immunizations were given on day 20 and day 40 (arrows). Data represent the mean $\pm \mathrm{SD}$ from three different experiments with five mice in each group. ${ }^{*} P<0.01$ versus control female mice.

permanent tolerance to challenging antigens. These data suggest that prolonged immunosuppression is associated with the continual presence of ISF in blood serum. It can also be assumed that the capability of receptors to bind ISF on the cell surface is renewed.

The results showing that the ISF suppressed the humoral response in vivo suggest potential uses of ISF in the model study in the treatment of antibody-mediated diseases. The seminal ISF is a potent immunosuppressive component with no apparent side effects on animals treated long-term in vivo. Attempts to suppress autoimmunity with biological agents encountered some obstacles. The treatment may have a longterm side effect on the immune system, as has been shown in studies showing a depletion of $\mathrm{CD} 4{ }^{+} \mathrm{T}$ cells in humans with rheumatoid arthritis (Lindsey et al., 1994: Moreland et al., 1994). This observation raised doubts about the long-term immune competence of the treated patients, and about the merits of a repeated course of therapy. The present preliminary study indicates that within a relatively short time after the cessation of ISF application, a normal immune response is restored. This characteristic may be particularly important in the treatment of autoimmune diseases with spontaneous remissions and relapses.

The authors thank M. Hošková and L. Koberová for their excellent technical assistance. This work was supported by Grant No. 303/96/ 0844 and the Complex Project Number 524-96-K 162 from the Grant Agency of the Czech Republic.

\section{References}

Ablin RJ and Gonder MJ (1985) Male accessory sexual glands secretions and their antithetical role in immunosurveillance. In Protides of the Biological Fluids pp 271-276 Ed. H Peeters. Pergamon Press, Oxford 
Ablin RJ, Bhatti RA, Bush JM and Guinan PD (1980a) Effect of humal seminal plasma on tumor-associated immunity in patients with adenocarcinoma of the prostate Journal of Reproductive Immunology 1 337-345

Ablin RJ, Bhatti RA, Bush JM and Guinan PD (1980b) Immunosuppression of cell- and serum-mediated tumor-associated immunity in prostatic cancer by human seminal plasma European Journal of Cancer 16 775-780

Ablin RJ, Bartkus JM and Polgar J (1990) Effect of human seminal plasma on the lytic activity of natural killer cells and presumptive identification of participant macromolecules Journal of Reproductive Immunology 24 15-21

Alexander NJ (1988) Antibodies to sperm and infertility. In Andrology and Human Reproduction pp 183-190 Eds A Negrovilar, A Isidori, J Paulsen, $R$ Abdelmassih and MPD Castro. Raven Press, New York

Alexander NJ and Anderson DJ (1987) Immunology of semen Fertility and Sterility 47 192-205

Anderson DJ and Hill JA (1989) Immunological aspects of the reproductive organs and implications of intercourse Current Opinion in Immunology 1 1119-1124

Anderson DJ and Tarter TH (1982) Immunosuppressive effect of mouse seminal plasma components in vivo and in vitro. Journal of Immunology $128535-539$

Bérube B and Sullivan R (1994) Inhibition of in vivo fertilization by active immunization of male hamster against a $26 \mathrm{kDa}$ sperm glycoprotein Biology of Reproduction 51 1255-1263

Chu TM, Nocera M, Flanders KC and Kawinski E (1996) Localization of seminal plasma transforming growth factor- $\beta 1$ on human spermatozoa: an immunocytochemical study Fertility and Sterility 66 327-330

De Simone C, Carreto G, Grassi PP, Covelli V, Lenzi A, Antonaci S and Jirillo E (1988) Inhibition of lymphocyte mediated antibacterial activity by human seminal plasma American Journal of Reproductive Immunology 17 1-4

Dostál J, Veselskyà L, Drahorád J and Jonáková V (1995) Immunosuppressive effect induced by intraperitoneal and rectal administration of boar seminal immunosuppressive factor Biology of Reproduction 52 1209-1214

Emoto M, Kita E, Nishikava F, Katsui N, Hamuro A, Oku D and Kashiba S (1990) Biological function of mouse seminal vesicle fluid II. Role of water-soluble fraction of seminal vesicle fluid as nonspecific immunomodulator Archives of Andrology 25 75-84

Emoto M, Nishikawa F, Oku D, Hamuro A, Kita E and Kashiba S (1991) Suppressive effect of mouse testicular extract on lymphocyte activation International Journal of Andrology 14 291-302

Goldiero F, Tufano MA, De Martino L, Caposso C, Porta R, Ravagnan G, Peluso G and Metafora $S$ (1989) Inhibition of macrophage phagocytic activity by SV-IV, a major protein secreted from the rat seminal vesicle epithelium Journal of Reproductive Immunology 16 269-284

Holdeman LV, Cato EP and Moore WEC (1977) Anaerobe Laboratory Manual (4th Edn) p. 144. Virginia Polytechnic Institute and State University, Blacksburg, VA

James K and Hargreave TB (1984) Immunosuppression by seminal plasma and its clinical significance Immunology Today 5 357-363

James K and Szymaniec S (1985) Human seminal plasma is a potent inhibitor of natural killer cell activity in vitro. Journal of Reproductive Immunology 8 61-70

Kelly RW, Quayle AJ, Wallace EM, Wu FCW, Hargreave TB and James K (1991) Immunosuppression by seminal plasma from fertile and infertile men: inhibition of natural killer cell function correlates with seminal PG concentration Prostaglandins Leukotrienes and Essential Fatty Acids 42 257-260
Lansdorp PM, Astaldi GCB, Oosterhof F, Janssen MC and Zeijlemaker WP (1980) Immunoperoxidase procedures to detect monoclonal antibodies against cell surface antigens. Quantitation of binding and staining of individual cells Joumal of Immunological Methods 39 393-405

Lindsey JW, Hodgkinson S, Mehta R, Mitchell D, Enzmann D and Steinman L (1994) Repeated treatment with chimeric anti-CD4 antibody in multiple sclerosis Annals of Neurology 36 183-189

Livi C, Pratesi S, Coccia E, Buzzoni P and Versari O (1990) Does intraperitoneal insemination in the absence of prior sensitization carry with it a risk of subsequent immunity to sperm? Fertility and Sterility 53 137-142

Moreland LW, Pratt PW, Bucy RP, Jackson BS, Feldman JW and Koopman WJ (1994) Treatment of refractory rheumatoid arthritis with a chimeric anti CD4 monoclonal antibody. Long-term follow up of $\mathrm{CD}^{+}{ }^{+} \mathrm{T}$ cell counts Arthritis and Rheumatism 37 834-839

Mori H, Nakayama K, Maeda D, Nagai H, Koda A, Kita J and Kaku Y (1994) Novel lowly immunosuppressive antitumor fluoridine derivative, UK 21: antitumor activity and effect of humoral immune response in mice Cancer Chemotherapy and Pharmacology 34 216-224

Nocera M and Chu TM (1993) Transforming growth factor $\beta$ as an immunosuppressive protein in human seminal plasma American Journal of Reproductive Immunology 30 1-8

Peitz B, Olds-Clarke P (1986) Effect of seminal vesicle removal on fertility and uterine sperm motility in the house mouse Biology of Reproduction 35 608-617

Peluso G, Porta R, Esposito C, Tufano MA, Tolardo R, Vuotto ML, Ravagnan G and Metafora S (1994) Suppression of rat epididymal sperm immunogenicity by a seminal vesicle secretory protein and transglutaminase both in vivo and in vitro. Biology of Reproduction 50 593-602

Quayle AJ, Kelly RW, Hargreave TB and James K (1989) Immunosuppression by seminal prostaglandins Clinical and Experimental Immunology 75 381-391

Ress RC, Vallely P, Clagg A and Potter CW (1986) Suppression of natural and activated human antitumour cytotoxicity by human seminal plasma Clinical and Experimental Immunology 63 687-695

Shivaji S, Scheit KH and Bhargava PM (1991) Immunosuppressive factors of seminal plasma. In Proteins of Seminal Plasma pp 375-389 Eds S Shivaji, KH Scheit and PM Bhargava. Wiley and Sons, New York

Skibinski G, Kelly RW and James K (1994) Expression of a common secretory granule specific protein as a marker for the extracellular organelles (prostasomes) in human semen Fertility and Sterility 61 755-759

Strzemienski PJ (1989) Effect of bovine seminal plasma on neutrophil phagocytosis of bull spermatozoa Journal of Reproduction and Fertility 87 519-528

Tarter TH, Cunningham-Rundles S and Koida S (1986) Suppression of natural killer cell activity by human seminal plasma in vitro: identification of $19-\mathrm{OH}$ PGE as the suppression factor Journal of Immunology 136 2862-2869

Veselský L, Čechová D, Hošková M, Štědra J, Holáń V and Staněk R (1991) In vivo and in vitro immunosuppression by boar seminal vesicle fluid fraction International Journal of Fertility 36 183-188

Veselský L, Holáň V, Souček J, Staněk R and Hošková M (1992) Effect of boar seminal plasma immunosuppressive factor on NK cell activity and skin graft survival International journal of Fertility 37 358-361

Veselský L, Dostál J, Holáñ V, Souček J and Železná B (1996) Effect of boar immunosuppressive fraction on B lymphocytes and on primary antibody response Biology of Reproduction 55 194-197 